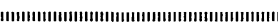

Original Article

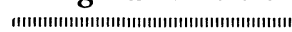

\section{Metabolism of Flutolanil in Rats}

\author{
Nobuyoshi Murakami, Matazaemon Uchida, Kunihiro Yabutani,* \\ Michinori OKADA** and Hiroyasu AizawA** \\ Institute of Life Science Research, Nihon Nohyaku Co., Ltd., \\ Honda-cho, Kawachi-Nagano, Osaka 586, Japan \\ *Chemical Research Center, Nihon Nohyaku Co., Ltd., \\ Tsukuda, Nishiyodogawa-ku, Osaka 555, Japan \\ **Mitsubishi-Kasei Institute of Toxicological and Environmental Sciences, \\ Kamoshida, Midori-ku, Yokohama 227, Japan
}

(Received April 8, 1983)

\begin{abstract}
The radiocarbon in $\left[\right.$ aniline ring- $\left.{ }^{14} C(U)\right]$ flutolanil, 3 '-isopropoxy-2-(trifluoromethyl)benzanilide, orally administered to male rats at the dose of 20 (or 100) $\mathrm{mg} / \mathrm{kg}$ was rapidly and almost completely excreted into urine and feces, 69 and 26 (or 67 and 30)\% of the dose, respectively, within $72 \mathrm{hr}$, although no radiocarbon was found in the expired $\mathrm{CO}_{2}$. Radiocarbon level in the blood reached the maximum of 4.2 (or 12.5) $\mu \mathrm{g}{ }^{14} \mathrm{C}$-flutolanil equivalent $/ \mathrm{ml}$ $2 \mathrm{hr}$ after administration, and then rapidly decreased. None of the tissues examined had a high residual radioactivity $72 \mathrm{hr}$ after administration $(20 \mathrm{mg} / \mathrm{kg})$. Small amounts of flutolanil were recovered from both of urine and feces $(2.3$ and $1.2 \%$ of the dose $20 \mathrm{mg} / \mathrm{kg}$, respectively). In the case of $20 \mathrm{mg} / \mathrm{kg}$, four metabolites identified were $3^{\prime}-(1$-hydroxycarbonylethoxy)-2-(trifluoromethyl)benzanilide (3), 4'-hydroxy-3'-isopropoxy-2-(trifluoromethyl)benzanilide (4), 3'-hydroxy-2-(trifluoromethyl)benzanilide (5) and 4'-hydroxy-3'-methoxy-2(trifluoromethyl) benzanilide (8). Their D-glucuronide and/or sulfate conjugates were also detected. The major metabolites were free and conjugated 5, which accounted for $57.5 \%$ of the dose $(51 \%$ in urine and $6.5 \%$ in feces). Those in bile accounted for $20 \%$ of the dose $(20 \mathrm{mg} / \mathrm{kg})$, much exceeding the fecal level. This should indicate the deconjugation, reabsorption and resulting exclusive excretion into urine as the sulfate. Metabolism of flutolanil in rats occurs through oxidative $O$-dealkylation and following conjugation. $4^{\prime}$-Hydroxylation also occurs but is not predominant. There was no evidence for cleavage of the anilide bond or hydroxylation on the 2-(trifluoromethyl)benzoyl ring.
\end{abstract}

\section{INTRODUCTION}

A new fungicide, flutolanil (Moncut ${ }^{\circledR}, 3^{\prime}$ isopropoxy-2-(trifluoromethyl)benzanilide), has been developed as an agent for controlling rice sheath blight caused by Rhizoctonia solani Kühn. ${ }^{1)}$ The fungicide is also effective against other diseases caused by Rhizoctonia, Corticium, Typhula and rust fungi. The fungicide is not highly toxic to mammals: oral $\mathrm{LD}_{50}$ more than $10 \mathrm{~g} / \mathrm{kg}$ and percutaneous $\mathrm{LD}_{50}$ more than $5 \mathrm{~g} /$ $\mathrm{kg}$ for rats and mice. No mutagenicity is shown by Ames assay. ${ }^{1)}$ Recently, the behavior in rice plant and soils has been studied in rela- tion to the hydrophobicity. ${ }^{2)}$ The fungicide which is not highly hydrophobic $(\log P=3.70)$, is not adsorbed strongly to the soil and is considerably mobile in rice plants. More recently, the metabolism of flutolanil in mammals has been studied in our Institutes. In the current paper, the metabolism of flutolanil orally administered to rats will be discussed.

\section{MATERIALS AND METHODS}

\section{Compounds}

[Aniline ring $\left.-{ }^{14} C(U)\right]$ flutolanil was synthesized by New England Nuclear (Boston, USA). The specific activity and the radiochemical 
Table 1 Authentic compounds and their $R f$ values.

\begin{tabular}{|c|c|c|c|c|}
\hline \multirow{3}{*}{$\begin{array}{c}\text { Compound } \\
\text { No. }\end{array}$} & \multirow{3}{*}{ Chemical structure } & \multicolumn{3}{|c|}{ Tlc $R f$ values } \\
\hline & & \multicolumn{3}{|c|}{ Solvent systems ${ }^{\mathrm{a})}$} \\
\hline & & $\mathrm{A}$ & B & $\mathrm{C}$ \\
\hline 1 & $\mathrm{CH}\left(\mathrm{CH}_{3}\right)_{2}$ & 0.54 & 0.58 & 0.68 \\
\hline 2 & 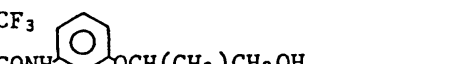 & 0.18 & 0.29 & 0.31 \\
\hline 3 & (methyl ester) & $\begin{array}{c}0.01 \\
(0.42)\end{array}$ & $\begin{array}{c}0.38 \\
(0.43)\end{array}$ & $\left(\overline{-b}^{\mathrm{b})}\right.$ \\
\hline 4 & $\mathrm{CH}_{3} \mathrm{CH}_{2}$ & 0.41 & 0.45 & 0.51 \\
\hline 5 & & 0.26 & 0.44 & 0.40 \\
\hline 6 & & 0.10 & 0.30 & - \\
\hline 7 & & 0.45 & 0.50 & - \\
\hline 8 & & 0.25 & 0.37 & - \\
\hline 9 & $\left(\mathrm{CH}_{3}\right)_{2}$ & 0.40 & 0.33 & 0.56 \\
\hline 10 & & 0.15 & 0.09 & 0.25 \\
\hline 11 & & 0.35 & 0.26 & 0.52 \\
\hline
\end{tabular}

a) A: chloroform/ethyl acetate (7/3), B: diisopropyl ether/acetonitrile/formic acid (18/1/1), $\mathrm{C}$ : dichloromethane/acetonitrile (4/1).

b) Not determined.

purity were $11 \mathrm{mCi} / \mathrm{mmol}$ and more than $99 \%$, respectively. Authentic compounds in Table 1 were prepared according to the methods reported previously as shown in Fig. $1,{ }^{3-7)}$ except compounds $\mathbf{1 0}$ and $\mathbf{1 1}$ which were commercially available. The properties of the synthesized compounds are as follows: 1 (flutolanil) $\mathrm{mp} 104-5^{\circ} \mathrm{C}, \delta$ (ppm) in $\mathrm{CDCl}_{3}$ $1.25(\mathrm{~d}, 6 \mathrm{H}), 4.49(1 \mathrm{H}), 6.5-7.8(\mathrm{~m}, 8 \mathrm{H})$ and 8.01 (broad, $1 \mathrm{H})$, IR $\nu_{\max }^{\text {nujol }}\left(\mathrm{cm}^{-1}\right) 1,650(\mathrm{CO})$ and $3,240(\mathrm{NH}), \mathrm{MS} m / z 323\left(\mathrm{M}^{+}\right), 281,173$ (base peak) and $145 ; 2 \mathrm{mp} 90.5-91.1^{\circ} \mathrm{C}, \delta$ (ppm) in $\mathrm{CDCl}_{3} 1.22(\mathrm{~d}, 3 \mathrm{H}), 2.48(\mathrm{~d}, 1 \mathrm{H}), 3.2-4.4(\mathrm{~m}$, $3 \mathrm{H})$ and $6.5-8.3(\mathrm{~m}, 9 \mathrm{H})$, MS $m / z 339\left(\mathrm{M}^{+}\right), 281$, 173 (base peak) and 145; 3 methyl ester $\delta(\mathrm{ppm})$ in $\mathrm{CDCl}_{3}, 1.50(\mathrm{~d}, 3 \mathrm{H}), 3.65(\mathrm{~s}, 3 \mathrm{H}), 4.68(\mathrm{q}$, $1 \mathrm{H}), 6.5-7.8(\mathrm{~m}, 8 \mathrm{H})$ and 8.28 (broad, $1 \mathrm{H})$, MS $m / z 367\left(\mathrm{M}^{+}\right), 308$ and 173 (base peak) (this was used as an authentic 3 for co-thin-layer chromatography after ester hydrolysis with $1 \mathrm{~N} \mathrm{NaOH}$ in aqueous acetone at $60^{\circ} \mathrm{C}$ for $1 \mathrm{hr}) ; \mathbf{4} \delta(\mathrm{ppm})$ in DMSO- $d_{6} 1.25(\mathrm{~d}, 6 \mathrm{H}), 4.48$ (se, $1 \mathrm{H})$ and 6.7-8.2 $(\mathrm{m}, 8 \mathrm{H})$, MS $m / z 339\left(\mathrm{M}^{+}\right)$, 297, 173 (base peak) and $145 ; 5 \mathrm{mp} 155-6^{\circ} \mathrm{C}$, $\delta(\mathrm{ppm})$ in DMSO- $d_{6} 6.3-8.0(\mathrm{~m}, 8 \mathrm{H}), 9.05(\mathrm{~s}$, $1 \mathrm{H})$ and 9.97 (broad, $1 \mathrm{H})$, MS $m / z 281\left(\mathrm{M}^{+}\right)$, 173 (base peak) and $145 ; 6 \mathrm{mp} 182-3^{\circ} \mathrm{C}, \delta(\mathrm{ppm})$ in DMSO- $d_{6} 6.6-8.0(\mathrm{~m}, 6 \mathrm{H}), 8.55$ (broad, $2 \mathrm{H}$ ) and $10.02(\mathrm{~s}, 1 \mathrm{H}) ; 7 \mathrm{mp} 113-5^{\circ} \mathrm{C}$, MS $m / z 295$ $\left(\mathrm{M}^{+}\right), 173$ (base peak) and $145 ; 8 \mathrm{mp} 190-5^{\circ} \mathrm{C}$, $\delta(\mathrm{ppm})$ in DMSO- $d_{6} 3.87(\mathrm{~s}, 3 \mathrm{H}), 6.73-7.8(\mathrm{~m}$, $7 \mathrm{H}), 8.03(\mathrm{~s}, 1 \mathrm{H})$ and 9.85 (broad, $1 \mathrm{H}), \mathrm{MS}$ $m / z 311\left(\mathrm{M}^{+}\right), 173$ (base peak) and 145; and $9 \mathrm{bp}(5 \mathrm{mmHg}) 120-2^{\circ} \mathrm{C}$. 


$$
1
$$

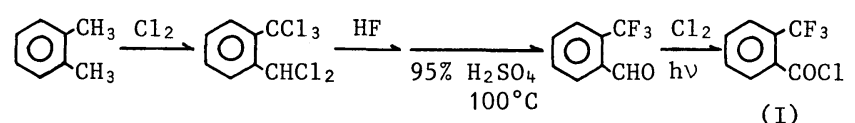

(I)

2

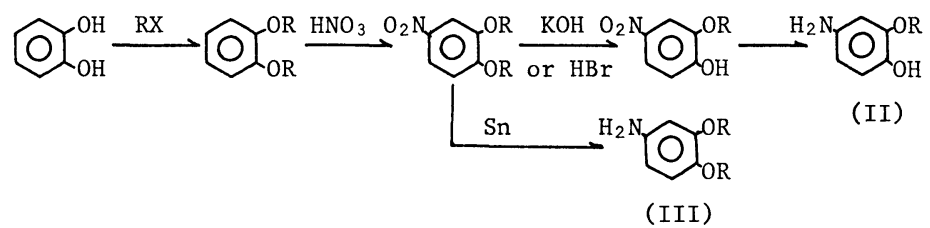

3

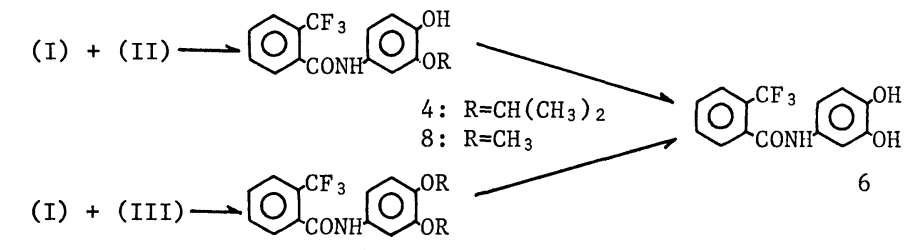

4

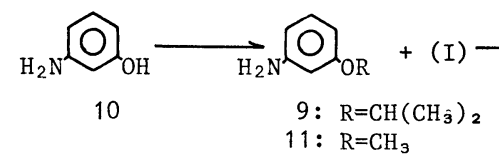

5
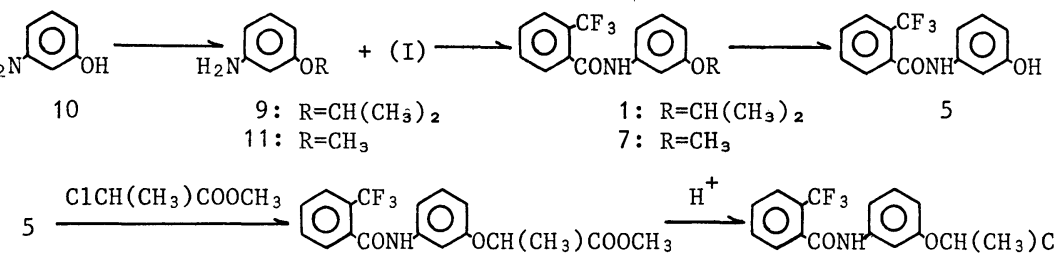

1: $\mathrm{R}=\mathrm{CH}\left(\mathrm{CH}_{3}\right)_{2}$

5

7: $\mathrm{R}=\mathrm{CH}_{3}$

3

$6 \mathrm{BrCH}\left(\mathrm{CH}_{3}\right) \mathrm{COOC}_{2} \mathrm{H}_{5} \stackrel{\mathrm{LiAlH}_{4}}{\longrightarrow} \mathrm{BrCH}\left(\mathrm{CH}_{3}\right) \mathrm{CH}_{2} \mathrm{OH} \longrightarrow$

Fig. 1 Route for synthesis of flutolanil and authentic compounds.

\section{Thin-layer Chromatography (tlc)}

Precoated silica gel plates $(20 \times 20 \mathrm{~cm}$, $0.25 \mathrm{~mm}$ thickness, E. Merck, Darmstadt, West Germany) were used for analytical and preparative procedures. The solvent systems used in $t l c$ and the obtained $R f$ values for authentic compounds are listed in Table 1. Radioactive metabolites or compounds on $t l c$ plates were autoradiographically detected using Fuji Rx film (Fuji Photo Company, Ltd., Tokyo, Japan). Cold compounds were detected by quenching of fluorescence under UV light with a wave length of $254 \mathrm{~nm}$ and/or by visualization with iodine gas.

\section{Radioassay}

For liquid scintillation counting $(l s c)$, a Packard Model 3255 or a Aloka LSC-903 liquid scintillation counter and a scintillation cocktail containing DPO $6 \mathrm{~g}$, POPOP $0.27 \mathrm{~g}$, naphthalene $60 \mathrm{~g}$, ethylene glycol $40 \mathrm{ml}$ and methanol $40 \mathrm{ml}$ in $920 \mathrm{ml}$ dioxane or ACS II ${ }^{\circledR}$ (Amersham Corp., Arlington Heights, Ill., USA) were used. A Packard Tri-Carb Model 306 sample oxidizer was used for determining total ${ }^{14} \mathrm{C}$ in feces, tissues or insoluble residues by combustion. Radiocarbon dioxide was trapped with Carbosorb ${ }^{\circledR}$, and added with Permaflor ${ }^{\circledR}$ (Packard Instrument Co., Downers Grove, Ill., USA) for lsc. An aliquot $(0.01-0.1 \mathrm{ml})$ of urine, bile or the extracts was introduced into vials containing $8-15 \mathrm{ml}$ of the scintillation mixture. The radioactivity on $t l c$ plates was determined by scraping appropriate regions into vials and by $l s c$. Counting efficiency and back ground were more than $80 \%$ and $30-40 \mathrm{dpm}$, respectively. 


\section{Animal Treatments}

Male Sprague-Dawley rats (7 week-old, weighing $199 \pm 9.5 \mathrm{~g})$ purchased from Charles River Japan Inc. (Atsugi, Japan) or Shizuoka Agriculture Cooperative Association for Laboratory Animals (Hamamatsu, Japan) were used. They (3 rats in each group) were orally administered with 20 (or 100 ) $\mathrm{mg} / \mathrm{kg}$ of ${ }^{14} \mathrm{C}$ flutolanil (250 or $25 \mu \mathrm{Ci} / \mathrm{kg}$, respectively) dissolved or suspended in $0.5 \mathrm{ml}$ olive oil and then housed individually in glass metabolic cages (Metabolica ${ }^{\circledR}$ CO-2, Sugiyamagen-Iriki, Tokyo, Japan, at $22-24^{\circ} \mathrm{C}$ and relative humidity $40-60 \%$ ), in which urine, feces and expired $\mathrm{CO}_{2}$ were separately collected for 5 days. The animals were supplied with diet (Charles River Japan Inc., Osaka, Japan) and tap water ad libitum throughout the experiment. During sampling urine and feces, they were kept at $0-5^{\circ} \mathrm{C}$ to prevent further alteration of metabolites. At various intervals after administration of ${ }^{14} \mathrm{C}$-flutolanil to rats (20 or $100 \mathrm{mg} / 100 \mu \mathrm{Ci} / \mathrm{kg}$ ), blood was collected from the tail vein and then transferred to combust pads, the total ${ }^{14} \mathrm{C}$ in which was determined by using the sample oxidizer and following $l s c$. For analysis of radiocarbon distribution in tissues and organs, rats were sacrificed at 30 min, 2, 12 or $72 \mathrm{hr}$ after administration $(20 \mathrm{mg} /$ $250 \mu \mathrm{Ci} / \mathrm{kg}$ ) and 10 major tissues were obtained. The radiocarbon levels were given as $\mu \mathrm{g}{ }^{14} \mathrm{C}$ flutolanil/g wet tissue or $\mathrm{ml}$ blood.

\section{Whole-body Autoradiography}

Rats orally administered with $20 \mathrm{mg} / 250$ $\mu \mathrm{Ci} / \mathrm{kg}$ of ${ }^{14} \mathrm{C}$-flutolanil were frozen $30 \mathrm{~min}, 2$, 6 or $72 \mathrm{hr}$ after administration and then mounted on the stage for a microtome JCMT1A (JEOL, Tokyo, Japan) at $-15^{\circ} \mathrm{C}$. Sagittal sections with $50 \mu \mathrm{m}$ thickness were obtained from appropriate levels to include representative organs. After lyophilization the sections were exposed on Fuji X-ray films (IX 150, Fuji Photo Company) at $-20^{\circ} \mathrm{C}$ for 2 weeks.

\section{Bile Collection}

The common bile duct of rats anaesthesized with diethyl ether was surgically cannulated with a polyethylene tube, through which the bile was collected for $24 \mathrm{hr}$ after administration $(20 \mathrm{mg} / 150 \mu \mathrm{Ci} / \mathrm{kg})$.

\section{Analysis and Identification of Metabolites}

The urine and feces, excreted from 3 rats for $24 \mathrm{hr}$ after administration at the dose of 20 $\mathrm{mg} / \mathrm{kg}$, were used. The diluted urine $(100 \mathrm{ml})$ was extracted three times with diethyl ether $(100 \mathrm{ml})$ at each $\mathrm{pH}$ of 7,2 and 10 . The combined extracts were concentrated for analysis. The aqueous residues were also analyzed by co-tlc with and without enzyme hydrolysis ( $\beta$-D-glucuronidase Type-I from bovine liver, Sigma Chemical Co., St. Louis, USA and arylsulfatase Type-V from limpets, Sigma Chemical Co., in $0.1 \mathrm{~m}$ acetate buffer of $\mathrm{pH} 5$ at $37^{\circ} \mathrm{C}$ for $24 \mathrm{hr}$ ) for determining the aglycons or the phenols. ${ }^{8)}$ The feces were lyophilized and then extracted three times with methanol $(30 \mathrm{ml})$ for $t l c$ analysis. The ${ }^{14} \mathrm{C}$ remaining in feces were re-extracted with water $(30 \mathrm{ml})$ and the obtained aqueous solutions were analyzed by co-tlc directly and after enzyme hydrolysis as described for urinary metabolites. Polar metabolites extracted from $t l c$ plates were subjected to enzyme hydrolysis. The bile was also analyzed by co-tlc directly or after enzyme hydrolysis. The metabolites in the extracts and bile were first separated and identified by two-dimensional co-tlc. Major metabolites purified by preparative $t l c$ were subjected to GCMS directly or after methylation with $\mathrm{CH}_{3} \mathrm{I}$ and $\mathrm{NaOH}$ in DMSO. The instruments used were a JEOL DX-300/JMA-3500 Mass Spectrometer (JEOL, Tokyo, Japan) and a Shimadzu GC-7A Gas Chromatograph (Shimadzu Corp., Kyoto, Japan) with flame ionized detector. A $1.5 \mathrm{~m}$ glass column packed with OV-1 2\% Chromosorb WHP (80-100 mesh) was used with $\mathrm{N}_{2}$ gas as the carrier $(40 \mathrm{ml} / \mathrm{min})$ at $230^{\circ} \mathrm{C}$.

\section{RESULTS}

\section{Radioactivity Level in Blood and Tissues (or Organs)}

The ${ }^{14} \mathrm{C}$ level in the blood rapidly increased to reach the maximum of 4.2 (or 12.5 ) $\mu \mathrm{g}{ }^{14} \mathrm{C}$ flutolanil equivalent/ml $2 \mathrm{hr}$ after an oral administration of the dose 20 (or 100) $\mathrm{mg} / \mathrm{kg}$, respectively. It then rapidly decreased with half lives of initially 4-6 hr and finally 16-18 hr (Fig. 2). That in the tissues of the rats given with $20 \mathrm{mg} / \mathrm{kg}{ }^{14} \mathrm{C}$-flutolanil also reached the maximum $2 \mathrm{hr}$ after administration and 


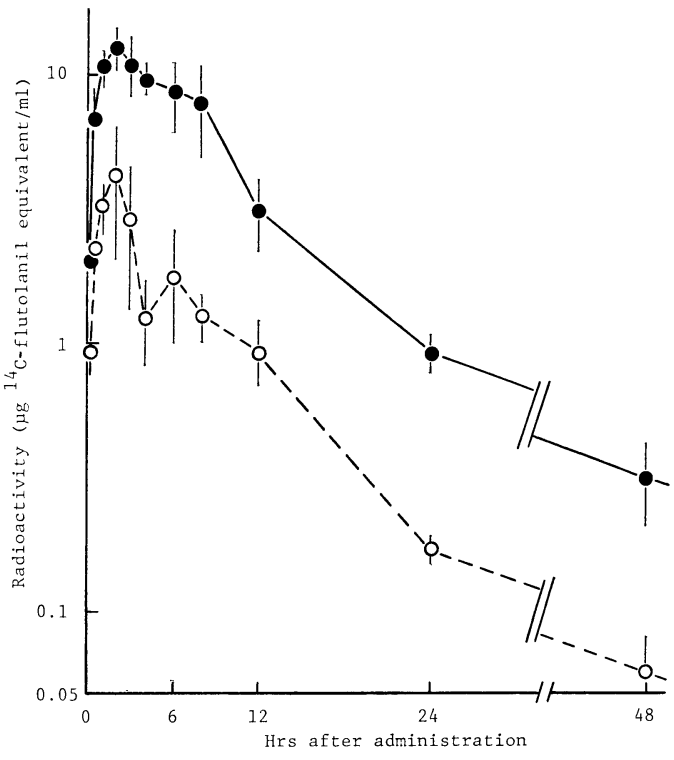

Fig. 2 Radioactivity in blood of the rats orally administered with ${ }^{14} \mathrm{C}$-flutolanil.

○: $20 \mathrm{mg} / \mathrm{kg}$, ๑: $100 \mathrm{mg} / \mathrm{kg}$.

then rapidly lowered (Table 2). Liver and kidney had the highest ${ }^{14} \mathrm{C}$ contents throughout the experiment. After $72 \mathrm{hr}$, the residual ${ }^{14} \mathrm{C}$ became negligible or very low in all of the tissues (Table 2).

In whole-body autoradiograms (Fig. 3), the highest ${ }^{14} \mathrm{C}$ density was found in the content of stomach and small intestine $30 \mathrm{~min}$ after administration, although liver and kidney already included low levels of ${ }^{14} \mathrm{C}$. After $2 \mathrm{hr}$, the ${ }^{14} \mathrm{C}$ was localized still in stomach and small intestine, although its distribution over the whole body was able to be seen. Within $6 \mathrm{hr}$, the highest ${ }^{14} \mathrm{C}$ density moved to small and large intestines, showing that the ${ }^{14} \mathrm{C}$ excretion through feces was occurring. The excretion was almost completed within $72 \mathrm{hr}$ so that low levels of ${ }^{14} \mathrm{C}$ remained only in small intestine, caecum and liver.

\section{Excretion}

Within $24 \mathrm{hr}, 64$ and 20 (61 and 21)\% of the radiocarbon in ${ }^{14} \mathrm{C}$-flutolanil administered orally at the dose of 20 (or 100) $\mathrm{mg} / \mathrm{kg}$ were excreted into urine and feces. The excretion gradually increased finally to 69 and 27 (67 and 30$) \%$ of the dose, respectively. After 3 days, no significant excretion of ${ }^{14} \mathrm{C}$ was observed. The ${ }^{14} \mathrm{C}$ in expired $\mathrm{CO}_{2}$ was negligible at the dose of $20 \mathrm{mg} / \mathrm{kg}$, although $34 \%$ of the ${ }^{14} \mathrm{C}$ was excreted into the bile within $24 \mathrm{hr}$ (Tables 3 and 4).

\section{Analysis of Metabolites}

The metabolites identified by co-tlc and their abundance in urine, feces and bile of the rats administered with $20 \mathrm{mg} / \mathrm{kg}$ of ${ }^{14} \mathrm{C}$-flutolanil are given in Table 5. The structures of $\mathbf{4 , 5}$ and 8 were also confirmed by GCMS: 4 Rt 7.0 min, MS $m / z 339\left(\mathrm{M}^{+}\right), 297,173$ (base peak) and $145 ; 5$ Rt $4.8 \mathrm{~min}, \mathrm{MS} m / z 281\left(\mathrm{M}^{+}\right), 173$ (base peak) and 145; dimethylated 5 Rt 2.7 min, MS $m / z 309\left(\mathrm{M}^{+}\right), 186,173$ (base peak)

Table 2 Radiocarbon distribution in tissues (or organs) after oral administration of ${ }^{14} C$ flutolanil at the dose of $20 \mathrm{mg} / \mathrm{kg}$ to rats.

\begin{tabular}{lcccc}
\hline \multirow{2}{*}{$\begin{array}{c}\text { Tissue } \\
\text { (or organ) }\end{array}$} & \multicolumn{4}{c}{$\mu \mathrm{g}{ }^{14} \mathrm{C}$-flutolanil equivalent/g wet tissue (or organ) $\left.{ }^{\mathrm{a}}\right)^{\prime}$} \\
\cline { 2 - 5 } & 0.5 & Hours after administration & 72 \\
\hline Adrenal & 0.4 & 2 & 12 & $<0.2^{\text {b) }}$ \\
Brain & $\leq 0.05$ & $0.9 \pm 0.4$ & $0.3 \pm 0.1$ & $<0.04$ \\
Fat & $0.22 \pm 0.05$ & $0.08 \pm 0.04$ & $\leq 0.04$ & $<0.15$ \\
Heart & $0.34 \pm 0.11$ & $0.51 \pm 0.16$ & $0.25 \pm 0.15$ & $<0.04$ \\
Kidney & $4.14 \pm 1.76$ & $10.17 \pm 3.17$ & $3.44 \pm 1.61$ & $0.05 \pm 0.02$ \\
Liver & $8.50 \pm 2.14$ & $15.38 \pm 2.79$ & $7.78 \pm 1.76$ & $0.85 \pm 0.15$ \\
Lung & $0.39 \pm 0.06$ & $1.43 \pm 0.74$ & $0.48 \pm 0.22$ & $<0.04$ \\
Muscle & $0.10 \pm 0.01$ & $0.31 \pm 0.14$ & $0.12 \pm 0.06$ & $<0.04$ \\
Spleen & $0.23 \pm 0.04$ & $0.47 \pm 0.14$ & $0.19 \pm 0.07$ & $<0.04$ \\
Testis & $0.12 \pm 0.09$ & $0.47 \pm 0.15$ & $0.25 \pm 0.09$ & $<0.04$
\end{tabular}

a) Each value represents the mean $\pm \mathrm{SD}$ of 3 rats. b) Lower than detection limit. 


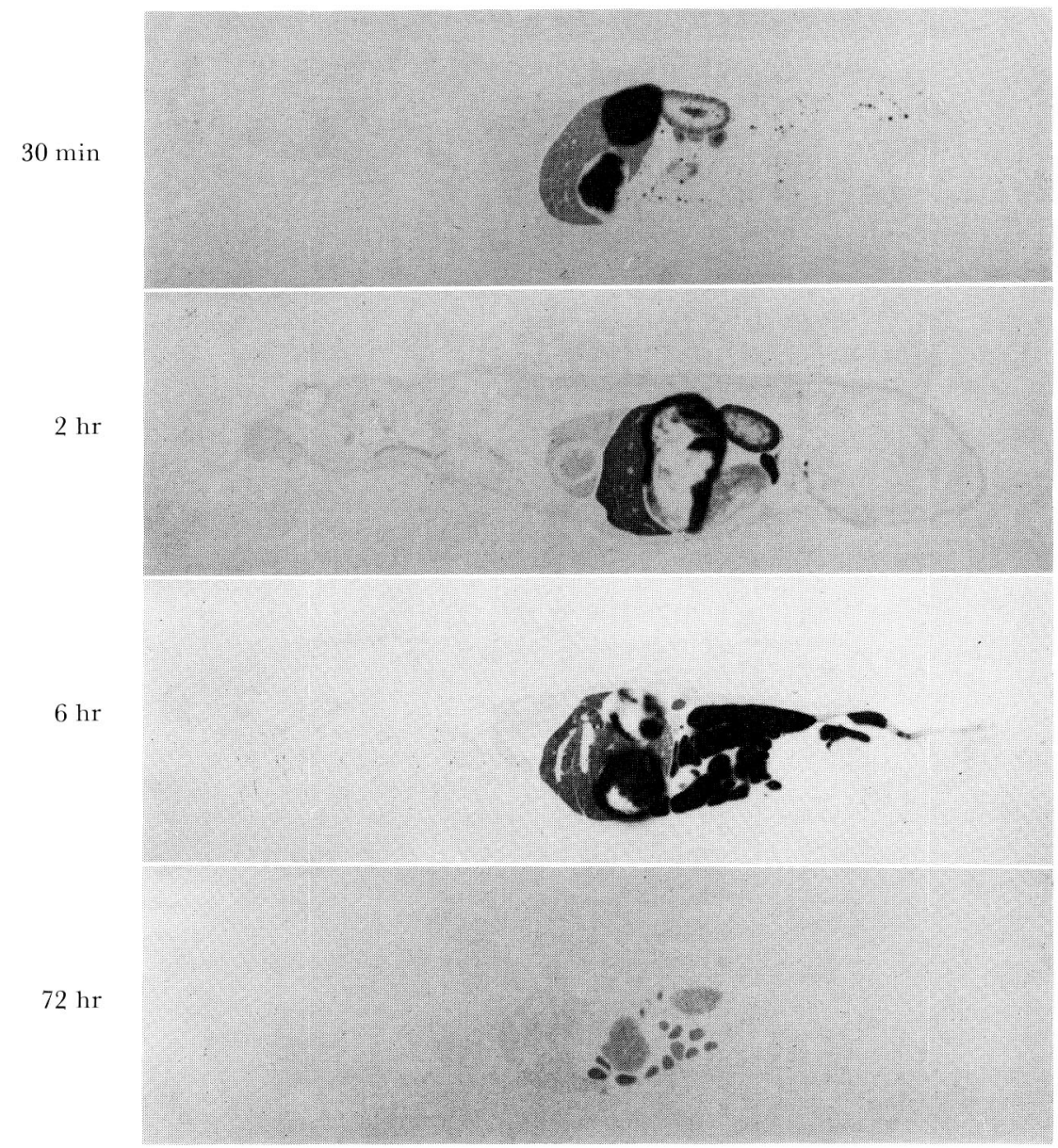

Fig. 3 Whole-body autoradiograms of rats orally administered with $20 \mathrm{mg} / 250 \mu \mathrm{Ci} / \mathrm{kg}$ of ${ }^{14} \mathrm{C}$-flutolanil.

Table 3 Cumulative ${ }^{14} \mathrm{C}$ excretion into urine, feces and expired ${ }^{14} \mathrm{CO}_{2}$ from rats administered 20 or $100 \mathrm{mg} / \mathrm{kg}$ of ${ }^{14} \mathrm{C}$-flutolanil.

\begin{tabular}{|c|c|c|c|c|c|c|c|}
\hline \multirow{3}{*}{$\begin{array}{l}\text { Days after } \\
\text { administration }\end{array}$} & \multicolumn{7}{|c|}{ Cumulative ${ }^{14} \mathrm{C}$ excretion ( $\%$ of dose $)^{a}$ ) } \\
\hline & \multicolumn{4}{|c|}{$20 \mathrm{mg} / \mathrm{kg}$} & \multicolumn{3}{|c|}{$100 \mathrm{mg} / \mathrm{kg}$} \\
\hline & Urine & Feces & $\underset{\mathrm{CO}_{2}}{\text { Expired }}$ & Total & Urine & Feces & Total \\
\hline 0.25 & $25.7 \pm 9.9$ & -b) & - & - & $27.1 \pm 2.9$ & - & - \\
\hline 0.5 & $48.3 \pm 9.1$ & - & - & - & $47.6 \pm 4.5$ & - & - \\
\hline 1 & $64.3 \div 5.8$ & $20.1 \pm 6.4$ & $<0.1$ & $84.5 \pm 0.6$ & $60.9 \pm 2.6$ & $21.4 \pm 1.6$ & $82.3 \pm 3.9$ \\
\hline 2 & $68.8 \pm 6.3$ & $25.9 \pm 6.5$ & $<0.1$ & $94.6 \pm 0.5$ & $66.0 \pm 1.1$ & $28.6 \pm 1.4$ & $94.7 \pm 0.7$ \\
\hline 3 & $69.1 \pm 6.4$ & $26.4+6.4$ & $<0.1$ & $95.5 \pm 0.5$ & $66.5 \pm 1.2$ & $29.6 \pm 1.5$ & $96.0 \pm 0.6$ \\
\hline 4 & $69.2 \pm 6.3$ & $26.5 \pm 6.3$ & $<0.1$ & $95.7 \pm 0.6$ & $66.6 \pm 1.1$ & $29.8 \pm 1.5$ & $96.4 \pm 0.7$ \\
\hline 5 & $69.3 \pm 6.3$ & $26.6 \pm 6.3$ & $<0.1$ & $95.9 \pm 0.6$ & $66.7 \pm 1.2$ & $29.9 \pm 1.5$ & $96.5 \pm 0.6$ \\
\hline
\end{tabular}

a) Each value represents the mean $\pm \mathrm{SD}$ of 3 rats. b) Not determined. 
Table 4 Cumulative ${ }^{14} \mathrm{C}$ excretion into bile from rats orally administered $20 \mathrm{mg} / \mathrm{kg}$ of ${ }^{14} \mathrm{C}$-flutolanil.

\begin{tabular}{ccc}
\hline $\begin{array}{c}\text { Hours after } \\
\text { administration }\end{array}$ & $\begin{array}{c}\text { Cumulative }{ }^{14} \mathrm{C} \text { excretion } \\
(\% \text { of dose })\end{array}$ \\
\hline 1 & $0.28^{\mathrm{a})}$ & $(0.14,0.41)$ \\
2 & 0.95 & $(0.38,1.51)$ \\
3 & 2.29 & $(0.65,3.91)$ \\
4 & 4.99 & $(2.85,7.11)$ \\
6 & 9.34 & $(8.05,10.61)$ \\
8 & 14.74 & $(11.95,17.51)$ \\
24 & 34.34 & $(25.95,42.71)$ \\
\hline
\end{tabular}

a) Each value represents the mean of two experiments.

and 145 and 8 Rt $6.4 \mathrm{~min}, \mathrm{MS} m / z 311\left(\mathrm{M}^{+}\right)$, 173 (base peak) and 145 .

From the urine, $2.3 \%$ of the administered ${ }^{14} \mathrm{C}$ was recovered as unchanged flutolanil, which was more than that in the feces $(1.22 \%)$. Four identified metabolites in the urine were $\mathbf{3}, \mathbf{4}, 5$ and $\mathbf{8}$, as well as their sulfate or $\beta$-Dglucuronide conjugates. Major metabolites in the urine were the sulfate and $\beta$-D-glucuronide of $\mathbf{5}$ which accounted for 37.3 and $12.1 \%$ of the ${ }^{14} \mathrm{C}$ dose, respectively. Free $5(1.2 \%$ of the dose) was much less than its conjugates. Metabolites 3, 4 and 8, including their conjugates, were also minor ones, accounting for $1.1,1.8$ and $2.2 \%$ of the dose, respectively.

Eight identified metabolites were obtained from the feces but all were in much less amounts. The major metabolite in the feces was free 5 (5.2\% of the dose). As the biliary metabolites identified, $\mathbf{4}$ and $\mathbf{5}$, four $\beta$-Dglucuronides (of $\mathbf{3}, \mathbf{4}, \mathbf{5}$ and $\mathbf{8}$ ) and three sulfates (of 4, $\mathbf{5}$ and $\mathbf{8}$ ) were detected, among which the sulfate of $\mathbf{5}$ was the major one $(16.8 \%$ of the dose).

There were several unidentified metabolites, none of which exceeded more than $1 \%$ of the dose except an unidentified metabolite A (free $2.4 \%$ and glucuronide $0.1 \%$ in the feces, and glucuronide $0.2 \%$ and sulfate $0.1 \%$ in the bile).

\section{DISCUSSION}

After administration of ${ }^{14} \mathrm{C}$-flutolanil at the dose of 20 (or 100 ) $\mathrm{mg} / \mathrm{kg},{ }^{14} \mathrm{C}$ was rapidly and exclusively excreted into urine and feces. Even 6 or $12 \mathrm{hr}$ after administration, 26 or $48(27$ or 48$) \%$ of ${ }^{14} \mathrm{C}$ was already recovered from the urine. Only $3.5 \%$ of administered ${ }^{14} \mathrm{C}$-flutolanil remained unchanged. Since most of ${ }^{14} \mathrm{C}$ was recovered as the metabolites, the fungicide seems to be easily metabolized in rats. The ${ }^{14} \mathrm{C}$ excreted into bile within $24 \mathrm{hr}$ was as much as $34 \%$ of the dose, which exceeds the fecal ${ }^{14} \mathrm{C}$ excretion (up to $26 \%$ of the dose even after $96 \mathrm{hr}$ ). Major metabolites in the bile were the sulfate or glucuronide conjugates, although those in the feces were free phenols. Therefore, the conjugated metabolites excreted into the bile seemed to be deconjugated in small intestine and probably reabsorbed. The

Table 5 Flutolanil metabolites and their abundance in urine, feces and bile of the rats orally administered with $20 \mathrm{mg} / \mathrm{kg}$ of ${ }^{14} \mathrm{C}$-flutolanil.

\begin{tabular}{|c|c|c|c|c|c|c|c|c|c|c|c|c|}
\hline \multirow{3}{*}{$\begin{array}{c}\text { Compound } \\
\text { No. }\end{array}$} & \multicolumn{12}{|c|}{ Abundance ( $\%$ of dose) of the metabolites excreted within $24 \mathrm{hr}$} \\
\hline & \multicolumn{4}{|c|}{ Urine } & \multicolumn{4}{|c|}{ Feces ${ }^{a)}$} & \multicolumn{4}{|c|}{ Bile } \\
\hline & Free & $\begin{array}{l}\text { Glucuro- } \\
\text { nide }\end{array}$ & $\begin{array}{l}\text { Sul- } \\
\text { fate }\end{array}$ & Total & Free & $\begin{array}{l}\text { Glucuro- } \\
\text { nide }\end{array}$ & $\begin{array}{l}\text { Sul- } \\
\text { fate }\end{array}$ & Total & Free & $\begin{array}{l}\text { Glucuro- } \\
\text { nide }\end{array}$ & $\begin{array}{l}\text { Sul- } \\
\text { fate }\end{array}$ & Total \\
\hline 1 & 2.3 & $-^{b)}$ & - & 2.3 & 1.2 & - & - & 1.2 & - & - & - & - \\
\hline 3 & 0.8 & 0.3 & - & 1.1 & 0.8 & 0.1 & - & 0.9 & -- & 1.5 & - & 1.5 \\
\hline 4 & 0.1 & 1.2 & 0.5 & 1.8 & 2.1 & - & - & 2.1 & 0.1 & 3.1 & 2.1 & 5.3 \\
\hline 5 & 1.2 & 12.1 & 37.3 & 50.6 & 5.2 & 0.3 & 0.8 & 6.5 & 0.6 & 3.0 & 16.8 & 20.4 \\
\hline 8 & 0.2 & 0.6 & 1.4 & 2.2 & - & - & 0.1 & 0.1 & - & 0.3 & 0.9 & 1.2 \\
\hline $\begin{array}{l}\text { Unidenti- } \\
\text { fied A }\end{array}$ & - & - & - & - & 2.4 & 0.1 & - & 2.5 & - & 0.2 & 0.1 & 0.3 \\
\hline
\end{tabular}

a) From feces, 68.2 and $18.2 \%$ of radioactivity were extracted with methanol and then with water, respectively.

b) Not detected. 


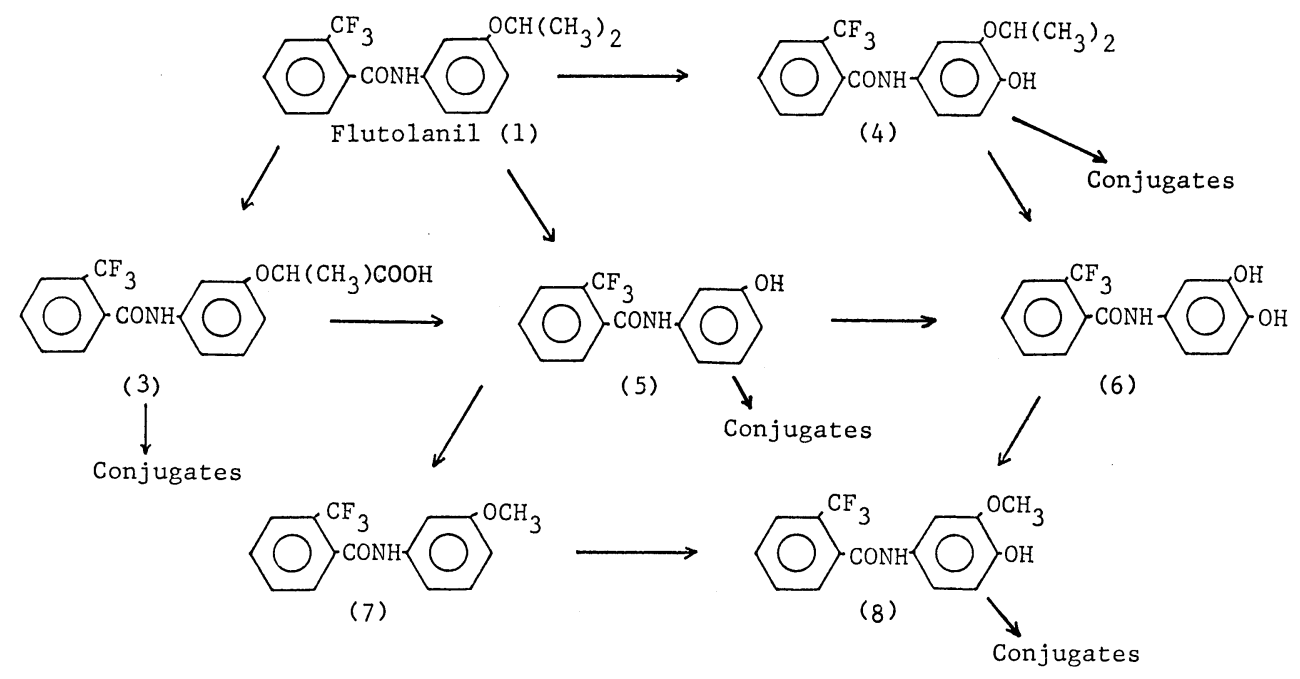

Fig. 4 Proposed metabolic pathways of ${ }^{14} C$-flutolanil in rats.

Compound 6 was not obtained as the metabolites but could be an important intermediates.

whole-body autoradiograms showed that, indeed, small intestine, caecum and liver still contained a significant level of radioactivity $72 \mathrm{hr}$ after administration but not large intestine and kidney. The blood level of radioactivity did not show a smooth decline (Fig. 2).

From the structure of identified metabolites, the metabolic pathways of flutolanil in rats can be proposed as shown in Fig. 4. The metabolism of flutolanil in rats occurred mainly through oxidative $O$-dealkylation and following conjugation. Although free and conjugated 4 were obtained from the urine and feces, 4'-hydroxylation seemed to be not predominant. There was no evidence for cleavage of the anilide bond and hydroxylation on the 2-(trifluoromethyl)benzoyl ring. However, the hydroxylation at the 3 or 5position of the 2-methylbenzoyl moiety of an analogous fungicide, mepronil, has been shown to occur. ${ }^{9)}$ This difference should be attributable to the electron withdrawal and donating effects of $\mathrm{CF}_{3^{-}}$and $\mathrm{CH}_{3-}$ substituents, respectively, on the benzoyl moiety and to the resulting difference in reactivity with electrophiles.

\section{ACKNOWLEDGEMENTS}

The authors thank Yoshio Izawa and Harumi Okayama for their skillful technical assistance.

\section{REFERENCES}

1) F. Araki \& K. Yabutani: Proc. Br. Crop Protec. Conf. Pest Dis., p. 3, 1981

2) M. Uchida, H. Nishizawa \& T. Suzuki: $J$. Pesticide Sci. 7, 397 (1982)

3) O. Schener: U.S. Pat. No. 2180772 (1940)

4) E. P. Clark: J. Am. Chem. Soc. 53, 3434 (1931)

5) Gillette Industries Ltd.: Br. Pat. No. 1063979, April 5 (1967)

6) R. F. Collins \& M. Davis: J. Chem. Soc. 1966, 366

7) R. F. Collins \& M. Davis: J. Chem. Soc. 1961, 1863

8) H. Kaneko, H. Ohkawa \& J. Miyamoto: $J$. Pesticide Sci. 6, 317 (1981)

9) Y. Asano, H. Inoue, I. Chiyomaru, T. Kitagaki, K. Kojima \& S. Baba: Annu. Meet. Pestic. Soc. Jpn. (Abstr.), p. 252, 1979

\section{要約}

\section{フルトラニルのラットにおける代謝}

村上信義，内田又左衛門，藪谷邦厷

岡田道則，相澤宏保

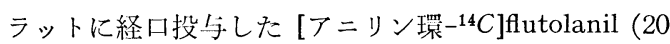
あるいは $100 \mathrm{mg} / \mathrm{kg})$ の放射能は速やかに尿打よび䔬中 に排泄され，呼気中 $\mathrm{CO}_{2}$ には検出されなかった，血中 放射能濃度は 2 時間後に最高值（それぞれ 4.2 あるいは $12.5 \mu \mathrm{g}{ }^{14} \mathrm{C}$-flutolanil 当量 $\left./ \mathrm{ml}\right)$ 飞達し，その後速やかに 隇少した. ${ }^{14} C$-flutolanil $(20 \mathrm{mg} / \mathrm{kg})$ 投与. 72 時間後に 
は,いずれの組織および器官にも高い放射能の残存はな かった．24時間までに得られた尿および䔬中にそれぞれ 投与量の 2.3 および $1.2 \%$ の flutolanil が検出された が, 多くは代謝物としてであり, 尿中に抱合型, 糞中に 遊離型として排泄されていた。代謝物として，3'-(1-hydroxycarbonylethoxy) - 2 - (trifluoromethyl) benzanilide (3), 4'-hydroxy-3'-isopropoxy-2-(trifluoromethyl)benzanilide (4), $3^{\prime}$-hydroxy-2-(trifluoromethyl) benzanilide (5) , 4'-hydroxy-3'-methoxy-2-(trifluoromethyl)benzanilide (8) およびそれらの抱合体 (glucuronide あるいは sulfate) が同定された。主代謝物は 5 であり，遊離型お
よび抱合型を合わせると，投与量の $57 \%$ (尿中に $51 \%$ ， 粪中に $6.5 \%$ ）を占めていた．胆汁中には 24 時間で 20 \%の 5 が，おもに (90\%以上) 抱合体の形で排泄されて いた．胆汁への 5 の抱合体の分泌量は䔬中への排泄量を 上回っており, 胆汁中抱合代謝物は腸内で脱抱合化さ れ，再吸収されることが示唆された，flutolanil のラッ トにおける代謝は, おもに脱一Oーアルキル化あるいはア ニリン環の水酸化を経て, 生成するフェノール類の抱合 によるものであり, ベンゾイル環の水酸化あるいはアニ リド結合の加水分解はみられなかった。 